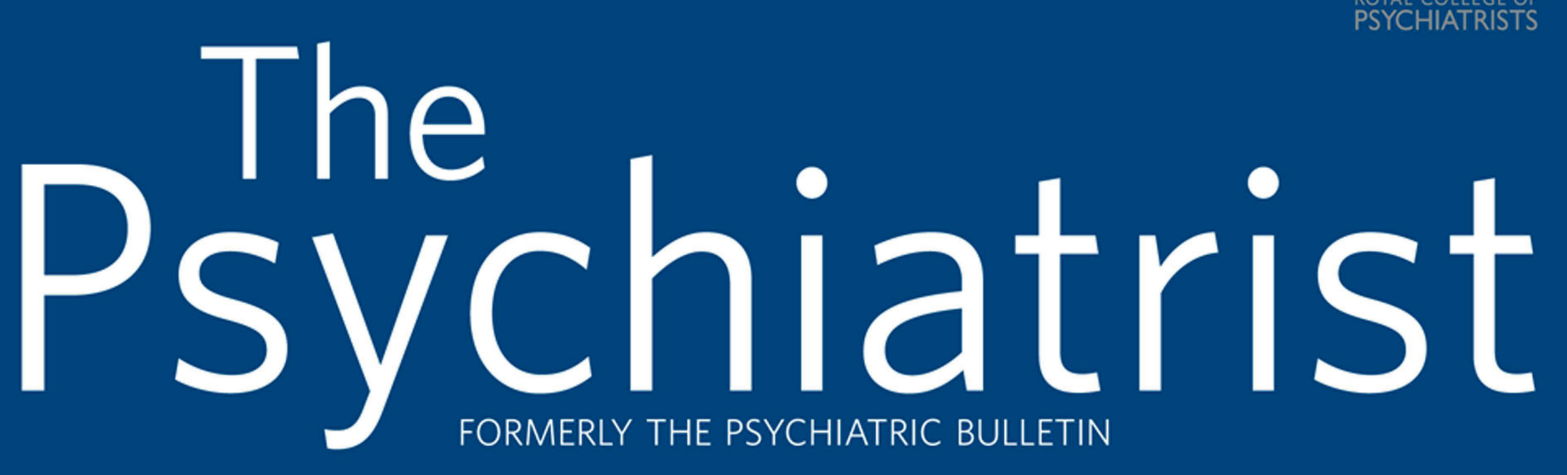

\title{
THIE FUTURE OF
} PSYCHOTHERAPY
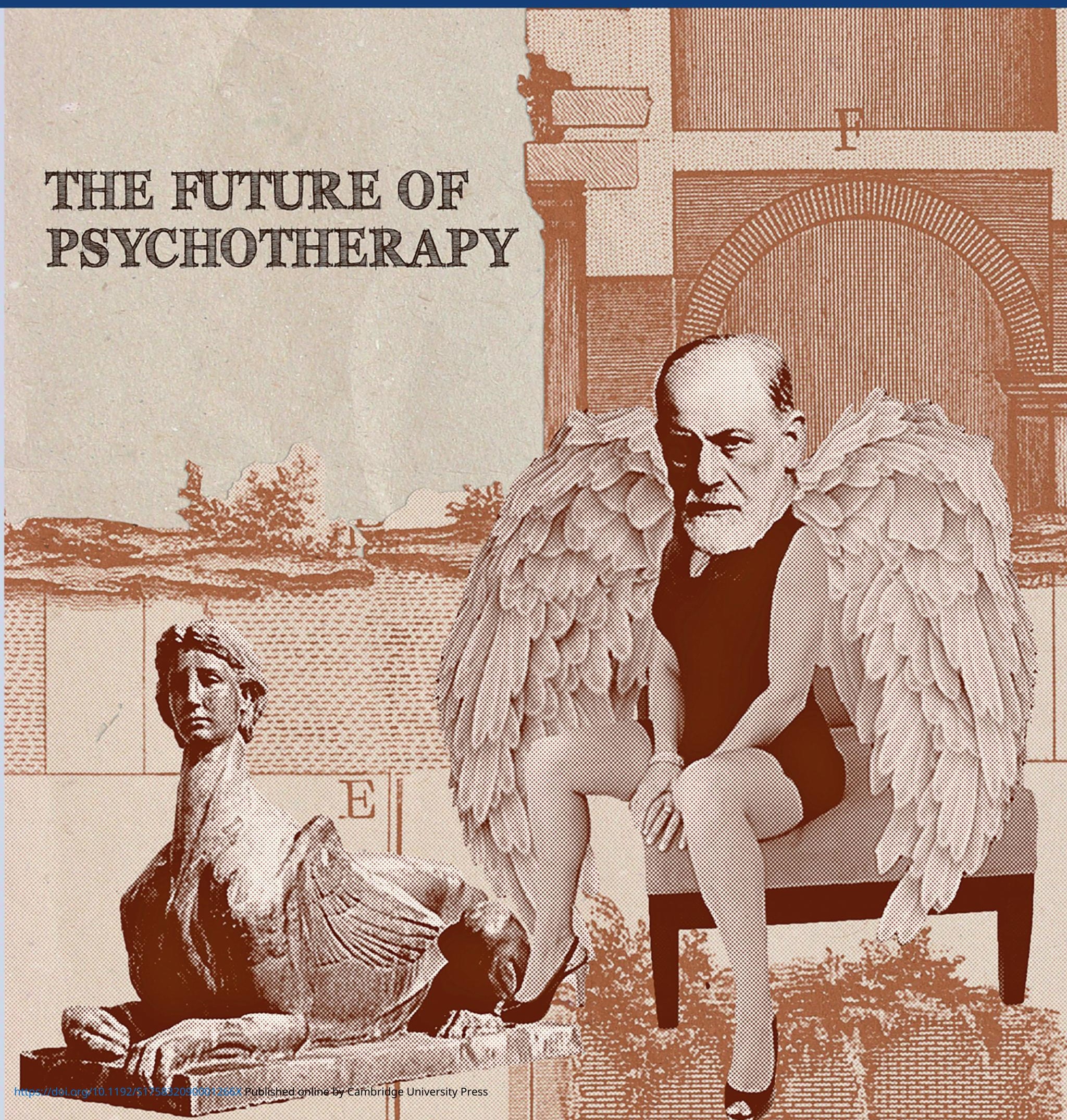